\title{
Kontribusi Kecerdasan Emosional dan Kebiasaan Belajar Terhadap Kompetensi Pengetahuan IPS
}

\author{
Ni Komang Darmiyanti ${ }^{1}$, DB.Kt.Ngr.Semara Putra ${ }^{2}$
}

${ }^{12}$ Prodi Pendidikan Guru Sekolah Dasar, Universitas Pendidikan Ganesha, Indonesia

\section{ARTICLEINFO Article history: Received 18 Desember 2019 \\ Received in revised form 30 Desember 2019 \\ Accepted 15 Januari 2020 \\ Available online 20 \\ Februari 2020 \\ Kata Kunci: \\ Dukungan Orang Tua, Minat \\ Baca, dan Motivasi Belajar}

Keywords:

Learning Motivation,

Parental Support, Reading

Interest terhadap kompetensi pengetahuan IPS (Y) diperoleh rhitung $=0,497>r_{\text {tabel }}=0,159$ ini berarti terdapat pengaruh yang signifikan, dan untuk kontribusi nilai koefisien korelasinya di kuadratkan $\mathrm{r}^{2}=0,4972=0,247$ berarti Sumbangan kontribusinya sebesar 24,7\%. Jadi, bahwa terdapat kontribusi yang signifikan kecerdasan emosional dan kebiasaan belajar berkontribusi terhadap kompetensi pengetahuan IPS siswa Kelas V SDN Gugus Mohhamad Hatta Kecamatan Denpasar Selatan tahun ajaran 2018/2019.

\section{A B S T R A C T}

This research aimed to know (1) the effect of emotional intelligence on civics competency, (2) the effect of study habits on the civics competency, and (3) the effect of both emotional intelligence and study habits on civics competency. This research was an ex post facto research. The population was 267 of 5 grades students at SDN Gugus Mohhamad Hatta Denpasar Selatan. The technique of choosing sample was proportional random sampling, consist of 152 students. The data, collected using questionnaire and analyzed by simple statistical regression and multiple regression. The effect of emotional intelligence $\left(X_{1}\right)$ on the civics competency $(Y)$ obtained $t_{\text {calculated }}=0,487>t_{\text {table }}=0,159$. It means that there was an effect of $\left(X_{1}\right)$ on $(Y)$ and the contribution is $r^{2}=\left(0,487^{2}\right)=0,238$. The percentage was $23,8 \%$. The effect of study habits on civics competency is $t_{\text {calculated }}=0,397>t_{\text {table }}=1,59$ which means there was an effect $\left(X_{2}\right)$ on $(Y)$ and the contribution was $r^{2}=\left(0,397^{2}\right)=0,158$. Hence, the contribution of $\left(X_{2}\right)$ on $(Y)$ was $15,8 \%$. Then, the effect of emotional intelligence and study habits on the civics competency score $r_{\text {calculated }}=0,497>r_{\text {table }}=0,159$. It said that there was an effect of emotional intelligence and study habits simultaneously on the civics competency $(Y)$. In knowing the contribution of coefficient of determination $r^{2}=0,4972=0,247$ the percentage is $24,7 \%$. So, emotional intelligence and study habits have significant contribution on civics competency of 5 grades students at SDN Gugus Mohamad Hatta Denpasar Selatan 2018/2019 academic year.

Copyright (C) Universitas Pendidikan Ganesha. All rights reserved.

\section{Pendahuluan}

Pendidikan adalah sebagai usaha sadar dan terencana untuk mewujudkan suasana belajar dan proses pembelajaran untuk peserta didik secara aktif mengembangkan potensi dirinya untuk memiliki kekuatasn spiritual keagamaan, pengendalian diri, keperibadian, kecerdasan, akhlak mulia, serta keterampilan yang diperlukan dirinya dan masyarakat. Kurikulum 2013 mengembangkan pengalaman belajar yang diberikan kesempatan luas bagi peserta didik untuk menguasai kompetensi yang diperlukan.

1 Corresponding author.

E-mail addresses: komingdarmiyanti@undiksha.ac.id¹(darmiyanti),semara.putra@undiksha.ac.id².(Semara)

\begin{abstract}
Penelitian ini bertujuan untuk mengetahui (1) Pengaruh kecerdasan emosional terhadap kompetensi pengetahuan IPS, (2) Pengaruh kebiasaan belajar terhadap
kompetensi pengetahuan IPS, dan (3) Pengaruh secara bersama-sama kecerdasan emosional dan kebiasaan belajar terhadap kompetensi pengetahuan IPS. Jenis ( kecerdasan emosional $\left(\mathrm{X}_{1}\right)$ terhadap kompetensi pengetahuan IPS (Y) dan untuk kontribusi nilai koefisien korelasinya di kuadratkan $r^{2}=0,4872=0,238$ terhadap kompetensi pengetahuan IPS(Y) diperoleh $r_{\text {hitung }}=0,397>r_{\text {tabel }}=0,159$ ini berarti terdapat pengaruh yang signifikan, dan untuk kontribusi nilai koefisien korelasinya di kuadratkan $\mathrm{r}^{2}=0,397^{2}=0,158$ berarti Sumbangan kontribusinya
\end{abstract} 然 (1) 
Di dalam pendidikan belajar adalah satu hal yang penting dalam meningkatkan pengetahuan peserta didik, belajar merupakan kegiatan memperoleh pengetahuan atau pengalaman yang berlangsung seumur hidup. Menurut Aunurrahaman (2016:35), "belajar adalah suatu proses yang dilakukan individu untuk memperoleh suatu perubahan tingkah laku yang baru secara keseluruhan, sebagai hasil pengalaman individu iu sendiri di dalam interaksi dengan lingkungan". Artinya, seseorang dalam proses interaksi dengan lingkungan di sekitarnya akan memperoleh pengalaman-pengalaman atau pengetahuanpengetahuan baru yang belum pernah dimilikinya. Proses interaksi yang dialami ini akan merubah tingkah laku atau cara pandang seseorang. Interaksi-interaksi seseorang dengan lingkungannya ini yang disebut sebagai kegiatan belajar, yang memungkinkan seseorang memperoleh hasil berupa perubahan dalam dirinya, baik itu peningkatan pengetahuan atau perubahan tingkah laku yang baru.

Berdasarkan definisi tersebut, kegiatan belajar dimulai dengan adanya stimulus atau kegiatan yang dilakukan oleh seseorang. Kegiatan ini akan masuk ke dalam ingatan orang yang sedang mengalami situasi tersebut. Semakin seseorang mendapatkan stimulus maka secara bertahap situasi stimulus itu akan mempengaruhi pola tingkah laku seseorang. Maka dapat dikatakan bahwa pola tingkah laku seseorang akan berubah dari waktu ke waktu setelah dia mengalami situasi stimulus. Dalam kegiatan belajar dari waktu ke waktu, seseorang akan memperoleh hasil, baik itu pengetahuan yang baru atau perubahan dalam kepribadiannya. Pengalaman-pengalaman dari kegiatan belajar inilah yang nantinya akan merubah kepribadian seseorang. Kepribadian yang dimaksud yaitu dalam hal keterampilan yang lebih baik setelah dia mengalami proses belajar, sikap yang lebih baik pula, kebiasaan-kebiasaan yang baru pun akan muncul. Begitu pula dengan pengetahuan dan kecakapannya, yang akan meningkat selama seseorang tersebut mengalami proses belajar. Hasil dari kegiatan belajar tersebut kemudian disebut sebagai hasil belajar. Ada banyak faktor yang mempengaruhi pencapaian hasil belajar siswa.

Faktor-faktor tersebut secara garis besar dikelompokkan menjadi dua, yaitu faktor internal dan eksternal. Faktor eksternal adalah faktor yang berasal dari luar diri siswa atau berasal dari lingkungan, Dilihat dari sudut faktor internal, faktor-faktor internal yang menimbulkan perbedaan hasil belajar antara satu siswa dengan siswa yang lain adalah kebiasaan belajar dan kecerdasan emosional, baik lingkungan keluarga, sekolah, ataupun masyarakat. Faktor internal merupakan faktor yang berasal dari dalam diri siswa itu sendiri. Hasil belajar yang dicapai banyak bergantung pada faktor-faktor tersebut yang saling berkaitan satu sama lain. Menurut Goleman (dalam Husna 2018) kecerdasan emosional atau yang biasa dikenal EQ adalah kemampuan seseorang untuk menerima, menilai, mengelola, serta mengontrol emosi dirinya dan orang lain di sekitarnya. Sedangkan Salovely dan Mayer (dalam Aunurrahman 2016) mendefinisikan "kecerdasan emosional sebagai kemampuan memantau dan mengendalikan perasaan sendiri dan orang lain, serta menggunakan perasaan-perasaan itu untuk memandu pikiran dan tindakan". Dalam hal ini, jika seseorang mempunyai kecerdasan emosional yang baik, dia akan mampu mengendalikan perasaannya. Saat seseorang merasa sedih, takut, marah atau senang, maka ia mampu mengendalikan perasaan tersebut agar tidak meluap secara berlebihan. Seseorang juga akan mampu mengendalikan perasaan orang lain dengan memberikan stimulus untuk memandu tindakan yang akan dilakukan oleh orang lain.

Dalam pembelajaran, kecerdasan emosional sangat diperlukan untuk dapat mengendalikan diri, memotivasi dirinya sendiri untuk dapat memperoleh hasil belajar secara optimal. Dengan memiliki kecerdasan emosional yang tinggi, siswa akan mampu mengontrol segala tindakan/perilaku yang dapat menghambat tercapainya hasil belajar secara optimal. Atau dengan kata lain, jika siswa memiliki kecerdasan emosional yang baik maka hasil belajar yang diperoleh akan optimal. Kecerdasan emosional memiliki beberapa aspek, Goleman (dalam Junairi 2017) menguraikan 5 aspek kecerdasan emosional seseorang, yaitu "kesadaran diri, pengaturan diri, motivasi diri, empati, dan kecakapan dalam membina hubungan dengan orang lain". Dapat dikatakan bahwa apabila kelima aspek tersebut baik, maka kecerdasan emosional seseorang akan baik pula. Selain kecerdasan emosional, kebiasaan belajar juga menjadi faktor yang mempengaruhi siswa dalam memperoleh hasil belajar yang optimal. Djaali (2009) yang menyatakan bahwa kebiasaan belajar bukan merupakan bakat ilmiah, tetapi merupakan perilaku yang dipelajari dengan sengaja dan sadar selama beberapa waktu tertentu. Pengulangan sepanjang waktu menyebabkan berbagai perilaku itu menjadi terbiasa sehingga terlaksana secara spontan. Dalam proses pembentukan kebiasaan belajar siswa, dapat dilakukan melalui kegiatan pembiasaan. Pembiasaan merupakan suatu proses pembentukan sikap yang dilakukan secara menetap melalui pengalaman berulang-ulang sampai pada tahap kemandirian. Perilaku yang menetap tersebut menjadi suatu kebiasaan. Lebih lanjut Djaali (2009) menyatakan bahwa "kebiasaan belajar juga dapat diartikan sebagai cara atau teknik yang menetap pada diri siswa pada waktu menerima pelajaran, membaca buku, mengerjakan tugas, dan pengaturan waktu untuk menyelesaikan kegiatan". Hasil belajar yang akan diperoleh sangat bergantung pada cara belajar siswa itu sendiri. Kebiasaan belajar ada kalanya 
merupakan kebiasaan belajar yang positif dan kebiasaan belajar yang negatif. Kebiasaan belajar yang positif akan membantu siswa menguasai materi pelajaran, sedangkan kebiasaan belajar yang negatif akan mempersulit mereka untuk memahami materi pelajaran. Kebiasaan belajar tidak dapat dibentuk dalam waktu satu hari atau satu malam. Kebiasaan belajar perlu dikembangkan sedikit demi sedikit. Slameto (dalam Susilowati 2017) mengemukakan aspek kebiasaan belajar yang perlu diperhatikan oleh seorang siswa adalah pembuatan jadwal dan pelaksanaannya, membaca dan membuat catatan, mengulangi bahan pelajaran, konsentrasi, dan mengerjakan tugas.

Berdasarkan hasil wawancara dan observasi di SDN 1, 2, 3,4 dan 6 Panjer diketahui masih banyak siswa yang tidak memiliki kebiasaan belajar yang baik. Seringkali siswa hanya belajar pada saat akan ada ulangan dan ujian saja, sehingga hasilnya jauh dari yang diharapkan. Siswa lebih senang bermain daripada membaca buku di perpustakaan pada saat jam istirahat, sehingga pemanfaatan waktu luang untuk belajar masih kurang dalam diri siswa. Apalagi ketika ada tugas rumah yang belum diselesaikan, siswa lebih memilih mengerjakan tugas tersebut daripada mengikuti pembelajaran yang sedang berlangsung. Kebiasaan mengerjakan PR di sekolah inilah yang menyebabkan siswa kurang memahami materi pembelajaran terutama dalam pembelajaran IPS karena dikerjakan dari hasil menyontek pekerjaan temannya.

Begitu pula halnya dengan kecerdasan emosional siswa yang kurang baik. Siswa seringkali bercanda saat mengikuti kegiatan pembelajaran, sehingga tidak memahami penjelasan guru. Selain itu, masih ada siswa yang kurang memiliki motivasi dalam belajar, siswa sering menyontek saat ada ulangan. Bahkan, siswa kurang bisa bekerjasama pada saat kegiatan kerja kelompok. Begitu pula saat kerja kelompok, siswa masih memilih teman-teman dekatnya saja untuk menjadi satu kelompok. Ini menunjukkan bahwa hubungan siswa kurang baik dengan teman-temannya di kelas. Buruknya kebiasaan belajar dan kecerdasan emosional siswa menyebabkan hasil belajar yang rendah pula terutama dalam kompetensi pengetahuan IPS.

Secara teoritik, kebiasaan belajar dan kecerdasan emosional memiliki kontribusi yang positif terhadap hasil belajar. Untuk membuktikannya, perlu dilakukan penelitian agar dapat diketahui seberapa besar kontribusi kebiasaan belajar dan kecerdasan emosional terhadap kompetensi pengetahuan IPS. Maka dari itu, penelitian ini dilakukan dengan tujuan untuk mengetahui kontribusi kecerdasan emosional dan kebiasaan belajar terhadap kompetensi pengetahuan IPS siswa kelas V SDN Gugus Mohhamad Hatta Kecamatan Denpasar Selatan tahun ajaran 2018/2019.

\section{Metode}

Penelitian ini merupakan penelitian ex post facto. Menurut Dantes (2012) menyatakan bahwa penelitian noneksperimen (ex post facto) merupakan suatu pendekatan pada subjek penelitian untuk meneliti yang telah dimiliki oleh subjek penelitian secara wajar tanpa adanya usaha sengaja memberikan perlakuan untuk memunculkan variabel yang ingin diteliti. Sedangkan menurut Sugiyono (2014) penelitian Ex post facto adalah penelitian yang dilakukan untuk meneliti peristiwa yang telah terjadi kemudian menuntut ke belakang untuk mengetahui factor-faktor yang dapat menimbulkan kejadian tesebut.

Sugiyono (2017) mengatakan bahwa "populasi adalah wilayah generalisasi yang terdiri atas objek/subjek yang mempunyai kualitas dan karakteristik tertentu yang ditetapkan oleh peneliti untuk dipelajari dan kemudian ditarik kesimplannya". dan untuk pengertian sampel Agung (2014:69) menyatakan bahwa "sampel ialah sebagian dari populasi yang diambil, yang dianggap mewakili seluruh populasi dan diambil dengan menggunakan teknik tertentu".

Populasi dan sampel dari SDN Gugus Mohhamad Hatta sebanyak 267 orang maka jumlah sampelnya sebanyak 152 orang. Teknik penentuan sampel ini adalah menggunakan teknik proposional random sampling yaitu penarikan sampel yang dilakukan secara random dengan memperhatikan proporsi jumlah siswa menurut lapisan kelas. Penentuan besarnya sampel dilihat pada tabel Issac and Michael pada jenjang pendidikan menggunakan tingkat kesalahan 5\%. Populasi dan sampel bisa dilihat ditabel 01.

Tabel 01 Rekapitulasi Populasi dan Sampel

Ni Komang Darmiyanti ${ }^{1}$, DB.Kt.Ngr.Semara Putra ${ }^{2} /$ Kontribusi Kecerdasan Emosional dan Kebiasaan Belajar Terhadap Kompetensi Pengetahuan IPS Siswa Kelas V 


\begin{tabular}{ccccc}
\hline No & Nama Sekolah & Kelas & Populasi & Sampel \\
\hline 1 & SD Negeri 1Panjer & V & 48 & 27 \\
2 & SD Negeri 2 Panjer & V & 61 & 28 \\
3 & SD Negeri 3 Panjer & V & 49 & 27 \\
4 & SD Negeri 4 Panjer & V & 61 & 35 \\
5 & SD Negeri 6 Panjer & V & 62 & 35 \\
\hline & Jumlah & & $\mathbf{2 6 7}$ & $\mathbf{1 5 2}$ \\
\hline
\end{tabular}

Pengumpulan data dilakukan dengan menggunakan kuesioner dan pencatatan dokumen. Kuesioner digunakan untuk pengumpulan data tentang kecerdasan emosional dan kebiasaan belajar. Jumlah butir kuesioner yaitu 25 butir soal untuk kecerdasan emosional dan 26 butir soal untuk kebiasaan belajar. Kuesioner yang digunakan untuk mengukur kebiasaan belajar dan kecerdasan emosional ini menggunakan kuesioner pola Likert. Pencatatan dokumen, digunakan untuk mengumpulkan data tentang kompetensi pengetahuan IPS, cara ini tidak memerlukan instrumen karena data yang dikumpulkan berupa nilai ulangan akhir sekolah yang sudah ada pada dokumen rekapitulasi nilai guru.

Kuesioner yang digunakan terlebih dahulu dilakukan pengujian yang meliputi uji pakar, uji validitas butir, dan uji reliabilitas. Uji pakar dilakukan oleh satu pakar. satu pakar akan memberikan penilaian terhadap kedua kuesioner, apakah kuesioner relevan atau tidak terhadap indikator yang telah ditentukan. Kemudian, untuk menguji validitas butir, terlebih dahulu dicari harga korelasi antara bagian-bagian dari alat ukur secara keseluruhan dengan cara mengkorelasikan setiap butir alat ukur dengan skor total yang merupakan jumlah tiap skor butir dengan rumus product moment dan selanjutnya dihitung dengan rumus uji-t. Kaidah keputusannya yaitu, jika $t_{\text {hitung }}>\mathrm{t}_{\text {tabel, }}$, maka butir tersebut valid. Jika $\mathrm{t}_{\text {hitung }}<\mathrm{t}_{\text {tabel, }}$ maka butir tersebut tidak valid. Selanjutnya, dilakukan uji reliabilitas menggunakan rumus Alpha cronbach. Butir kuesioner yang dihitung reliabilitasnya hanya butir-butir yang valid sedangkan butir-butir yang drop (gugur) tidak digunakan. Hasil dari $\mathrm{r}_{11}$ kemudian dikonsultasikan dengan nilai $\mathrm{r}$ tabel dengan $\mathrm{dk}=\mathrm{n}-1$ pada taraf signifikansi 5\%. Dasar pengambilan keputusan yaitu, "jika $r_{11}>r$ tabel, maka perangkat kuesioner tersebut reliabel. Jika $\mathrm{r}_{11}<\mathrm{r}$ tabel, maka perangkat kuesioner tersebut tidak reliabel".

Analisis data dalam penelitian ini dilaksanakan dalam 2 tahap yaitu, (1) analisis data untuk prasyarat analisis, dan analisis data untuk uji hipotesis. Analisis data untuk prasyarat analisis dilakukan uji normalitas, uji linearitas,uji multikolinearitas dan uji heterkedastisitas.

Uji Normalitas untuk mengetahui apakah sebaran data skor penguasaan kecerdasan emosional, kebiasaan belajar dan kompetensi pengetahuan IPS siswa masing-masing kelompok berdistribusi normal atau tidak sehingga dapat menentukan teknik analisis datanya. Uji Normalitas yang digunakan pada peneliti ini mengunakan Uji Kolomogorov-smirnov. Kriteria pengujian adalah nilai $\left|\mathrm{F}_{\mathrm{T}}-\mathrm{F}_{\mathrm{S}}\right|_{\text {terbesar }}$ kurang dari nilai tabel Kolmogorov-Smirnov, maka $\mathrm{H}_{0}$ diterima; $\mathrm{H}_{\mathrm{a}}$ ditolak. Jika nilai $\left|\mathrm{F}_{\mathrm{T}}-\mathrm{F}_{\mathrm{S}}\right|$ terbesar lebih besar dari nilai tabel Kolmogorov-Smirnov, maka $\mathrm{H}_{0}$ ditolah.

Uji linearitas digunakan rumus regresi sederhana. Dasar pengambilan keputusan yaitu, harga $\mathrm{F}$ hitung (regresi) lebih besar dari harga $\mathrm{F}$ tabel pada taraf signifikansi 5\%, maka $\mathrm{F}$ hitung (regresi) signifikan, yang berarti bahwa koefisien regresi adalah berarti (bermakna). harga $\mathrm{F}$ hitung (tuna cocok) lebih kecil dari harga $\mathrm{F}$ table pada taraf signifikansi 5\%, maka $\mathrm{F}$ hitung (tuna cocok) tidak signifikan, yang berarti regresi $\mathrm{Y}$ atas $\mathrm{X}$ adalah linier.

Uji multikolinearitas menggunakan aplikasi SPSS 21 for windows, dengan melihat nilai VIF dan nilai Tol nya. Kriteria pengujian untuk mengetahui terjadi atau tidaknya multikolinearitas adalah jika nilai Tol $<0,1$ atau nilai VIF $>10$, maka $\mathrm{H}_{0}$ diterima atau dikatakan terjadi multikoleniaritas. Selanjutnya untuk uji Heteroskesdastistas mengunakan uji glejser pada SPSS 21 for windows. Dengan kriteria nilai t statistic dari seluruh variabel penjelas tidak ada yang signifikan $(p>0,05)$ sehingga tidak mengalami masalah heterokesdastistas.

Analisis data untuk uji hipotesis I dan II digunakan teknik analisis regresi sederhana, Uji regresi linier sederhana yaitu regresi linier dengan satu variabel prediktor (bebas). Bentuk persamaannya adalah sebagai berikut.

$$
\widehat{Y}=a+b X
$$

Keterangan:

$\mathrm{a}=$ konstanta (bilangan konstan)

$\mathrm{b}=$ koefisien arah regresi 


$$
\begin{aligned}
a & =\frac{\mathrm{n}\left(\sum \mathrm{Y}\right)\left(\sum \mathrm{X}^{2}\right)-\left(\sum \mathrm{X}\right)\left(\sum \mathrm{XY}\right)}{\mathrm{n} \sum \mathrm{X}^{2}-\left(\sum \mathrm{X}\right)^{2}} \\
\mathrm{~b} & =\frac{\mathrm{n} \sum \mathrm{XY}\left(\sum \mathrm{X}\right)\left(\sum \mathrm{Y}\right)}{\mathrm{n} \sum \mathrm{X}^{2}-\left(\sum \mathrm{X}\right)^{2}}
\end{aligned}
$$

Kemudian dilanjutkan dilakukan uji sigifikan regresi dan uji t, untuk mengetahui pengaruh antara variabel bebas(X) dan variabel terikat(Y). Kaidah pengujian yaitu, jika $\mathrm{t}$ hitung $\geq \mathrm{t}$ tabel, maka $\mathrm{H}_{0}$ ditolak, artinya signifikan, dan jika $\mathrm{t}_{\text {hitung }} \leq \mathrm{t}_{\text {tabel, }}$, maka $\mathrm{H}_{0}$ diterima, artinya tidak signifikan pada taraf signifikansi $5 \%$.

Analisis data untuk uji hipotesis III digunakan teknik analisis regresi ganda dan dilanjutkan dengan uji signifikansi menggunakan rumus F pada taraf siginifikansi 5\% menggunakan. Dalam uji regresi ganda ini merupakan model regresi linier dengan melibatkan lebih dari satu variabel bebas atau prediktor. Jika terdapat dua variabel bebas $\left(\mathrm{X}_{1}\right)$ dan $\left(\mathrm{X}_{2}\right)$ serta variabel terikat $(\mathrm{Y})$ Adapun perasamaan garis regresi linier berganda sebagai berikut

$$
\hat{Y}=a+b_{1} X_{1}+b_{2} X_{2}
$$

(Koyan,2012)

Menentukan koefisien-koefisien $\left(b_{1}\right.$ dan $\left.b_{2}\right)$ dan konstanta (a) persamaan regresi ganda menggunakan rumus.

Menentukan koefisien-koefisien $\left(b_{1}\right.$ dan $\left.b_{2}\right)$ dan konstanta (a) persamaan regresi ganda, yaitu dengan rumus :

(a) Koefisien regresi $X_{1}$

Rumus:

$$
b_{1}=\frac{\left(\sum \mathrm{x}_{2}^{2}\right)\left(\sum \mathrm{x}_{1} \mathrm{y}\right)-\left(\sum \mathrm{x}_{1} \mathrm{x}_{2}\right)\left(\sum \mathrm{x}_{2} \mathrm{y}\right)}{\left(\sum \mathrm{x}_{1}^{2}\right)\left(\sum \mathrm{x}_{2}^{2}\right)-\left(\sum \mathrm{x}_{1} \mathrm{x}_{2}\right)^{2}}
$$

(b) Koefisien regresi $\mathrm{X}_{2}$

Rumus:

$$
b_{2}=\frac{\left(\sum \mathrm{x}_{1}^{2}\right)\left(\sum \mathrm{x}_{2} \mathrm{y}\right)-\left(\sum \mathrm{x}_{1} \mathrm{x}_{2}\right)\left(\sum \mathrm{x}_{1} \mathrm{y}\right)}{\left(\sum \mathrm{x}_{1}^{2}\right)\left(\sum \mathrm{x}_{2}^{2}\right)-\left(\sum \mathrm{x}_{1} \mathrm{x}_{2}\right)^{2}}
$$

(c) Konstanta regresi ganda

Rumus:

$$
a=\frac{\sum Y}{n}-b_{1}\left(\frac{\sum x_{1}}{b}\right)-b_{2}\left(\frac{\sum x_{g}}{n}\right)
$$

(Koyan, 2012)

Selanjutnya melakukan Uji F dengan ketentuan jika $\mathrm{F}_{\text {hitung }} \geq \mathrm{F}_{\text {tabel, }}$, maka tolak $\mathrm{H}_{0}$ artinya signifikan dan jika $\mathrm{F}_{\text {hitung }} \leq \mathrm{F}_{\text {tabel, }}$, terima $\mathrm{H}_{0}$ artinya tidak signifikan. Mencari koefisien determinasinya untuk mengetahui kontribusi yang diberikan variabel bebas $(\mathrm{X})$ terhadap variabel terikat $(\mathrm{Y})$. Uji koefisien korelasi berganda (R).

\section{Hasil Dan Pembahasan}

Berdasarkan hasil uji pakar, kuesioner yang diujikan mendapat perbaikan dari dosen pakar. Setelah dilakukan perbaikan maka kuesioner dapat digunakan untuk melanjutkan uji validitas butir. Uji validitas butir dilakukan dengan cara membagikan koesioner kepada siswa di sekolah. Uji validitas butir ini dilakukan untuk mengetahui banyaknya butir soal yang layak digunakan dalam proses pengumpulan data. Setelah kuesioner disebar kemudian akan dilakukan perhitungan menggunakan rumus product moment

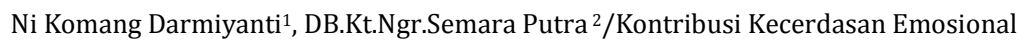
dan Kebiasaan Belajar Terhadap Kompetensi Pengetahuan IPS Siswa Kelas V 
yang kemudian dilanjutkan dengan rumus t-hitung. Hasil dari t-hitung akan dibandingkan dengan t-tabel dengan kaidah keputuasan, jika t-hitung lebih besar dari t-tabel, maka butir soal tersebut valid.

Dari hasil perhitungan kuesioner kebiasaan belajar, dapat disimpulkan dari 35 butir soal yang diujikan hanya 30 butir yang valid atau layak dipakai, sedangkan 5 butir soal tidak valid. Jadi, butir soal kuesioner yang dapat digunakan dalam penelitain yaitu 30 butir. Dari hasil perhitungan kuesioner kecerdasan emosional, dapat disimpulkan dari 35 butir soal yang diujikan hanya 30 butir yang valid atau layak dipakai, sedangkan 5 butir soal tidak valid. Jadi, butir soal kuesioner yang dapat digunakan dalam penelitain yaitu 30 butir. Dari hasil uji validitas butir, kemudian dilakukan uji reliabilitas pada butir soal yang valid. Berdasarkan perhitungan uji reliabilitas kebiasaan belajar diperoleh nilai $r_{\text {hitung }}=0,826>r_{\text {tabel }}$ $=0,227$ pada taraf signifikansi 5\% yang berarti kuesioner kebiasan belajar reliabel. Dan hasil perhitungan reliabelitas kecerdasan emosional diperoleh nilai $r_{\text {tabel }}=0,227$ pada taraf signifikansi $5 \%$ yang berarti kuesioner kecerdasan emosional reliabel.

Model regresi yang baik adalah yang memiliki nilai residual yang terdistribusi secara normal. Berdasarkan uji normalitas data yang telah dilakukan dengan perhitungan menggunakan program SPSS 21.0 for windows maka, didapatkan hasil perhitungan uji normalitas residual dengan menggunakan rumus Kolmogorov - Smirnov sebagai berikut.

Tabel 02 Hasil Uji Normalitas Nilai Residual Data menggunakan Program SPSS 24.0 for windows

\begin{tabular}{cccc}
\hline Variabel & $\begin{array}{c}\text { Asymp. Sign (2- } \\
\text { talled) }\end{array}$ & Signifikansi & Keterangan \\
\hline X1 dengan Y & 0.322 & 0.05 & Berdistribusi normal \\
X2 dengan Y & 0.664 & 0.05 & Berdistribusi normal \\
X1 dan X2 dengan Y & 0.319 & 0.05 & Berdistribusi normal \\
\hline
\end{tabular}

Berdsarkan data tersebut, uji normalitas nilai residual dengan menggunakan spss 24.0 for windows memperoleh nilai asymp. sign (2-talled) 0.322 untuk x1 dengan y, 0.664 untuk $\mathrm{x} 2$ dengan y, dan 0,319 untuk $\mathrm{x}_{1}$ dan $\mathrm{x}_{2}$ dengan $\mathrm{y}$. nilai yang diperoleh tersebut lebih besar dari taraf signifikansi yaitu 0.05 . Jadi, dapat disimpulkan bahwa data nilai residual berdistribusi normal.

Tabel 03 Hasil Uji Linieritas Data

\begin{tabular}{cccc}
\hline Variabel & $\boldsymbol{F}_{\text {hitung }}$ & $\boldsymbol{F}_{\text {tabel }}$ & Keterangan \\
\hline $\begin{array}{c}\text { Kecerdasan Emosional dengan } \\
\text { Kompetensi Pengetahuan IPS }\end{array}$ & 1,324 & 1,55 & Linier \\
$\begin{array}{c}\text { Kebiasaan Belajar dengan } \\
\text { Kompetensi Pengetahuan IPS }\end{array}$ & $-0,128$ & 1,55 & Linier \\
\hline
\end{tabular}

Berdasarkan perhitungan uji linearitas untuk hubungan variabel kecerdasan emosional dengan kompetensi pengetahuan IPS adalah $\mathrm{F}_{\text {hitung }}(\mathrm{tc})=1,324<\mathrm{F}_{\text {tabel }}(\mathrm{tc})=1,55$, maka dapat disimpulkan bahwa regresi $\mathrm{X}_{1}$ terhadap $\mathrm{Y}$ adalah linier. Selanjutnya untuk hubungan variabel kebiasaan belajar dengan kompetensi pengetahuan IPS adalah $\mathrm{F}_{\text {hitung }}(\mathrm{tc})=-0,123<\mathrm{F}_{\text {tabel }}(\mathrm{tc})=1,55$, maka dapat disimpulkan bahwa regresi $\mathrm{X}_{2}$ terhadap $\mathrm{Y}$ berpola linier.

Hasil uji multikolinearitas diketahu nilai Tolerance Variabel Kecerdasan Emosional $\left(\mathrm{X}_{1}\right)$ dan Kebiasaan Belajar $\left(\mathrm{X}_{2}\right)$ sebesar 0,554 > 0,10 dan nilai VIF variabel Kecerdasan Emosional dan Kebiasaan Belajar $\left(\mathrm{X}_{2}\right)$ sebesar $1,806<10$. maka dapat disimpulkan bahwa tidak terjadi multikolinearitas dan memenuhi uji prasyarat analisis.

Hasil uji heteroskedastisitas digunakan untuk melihat apakah terdapat ketidaksamaan varian dan residual satu pengamatan ke pengamtan yang lain. Berdasarkan hasil heteroskedastisitas menggunakan program SPSS 21.0 for windows tersebut, diperoleh nilai Sig. kedua variabel independen kecerdasan Emosional $=0.714$ dan Kebiasaan Belajar $=0.386$ lebih dari 0.05. Jadi, dapat disimpulkan tidak terjadi heteroskedastisitas pada model regresi.

Analisis uji hipotesis pertama yaitu $\mathrm{H}_{0}$ : Tidak terdapat pengaruh kecerdasan emosional terhadap kompetensi pengetahuan IPS Siswa kelas V SD Gugus Mohhamad Hatta Denpasar Selatan tahun ajaran 2018/2019. Berdasarkan perhitungan diperoleh data koefisien $a=44,541$ dan $b=0,507$. Jadi model persamaan regresinya adalah $\breve{Y}=41,181+0,550 \mathrm{X}_{1}$ atau kompetensi pengetahuan IPS $=41,181+0,550$ kecerdasan emosional. 
Hasil persamaan regresi tersebut dapat digambarkan dengan garis regresi yaitu sebagai berikut.

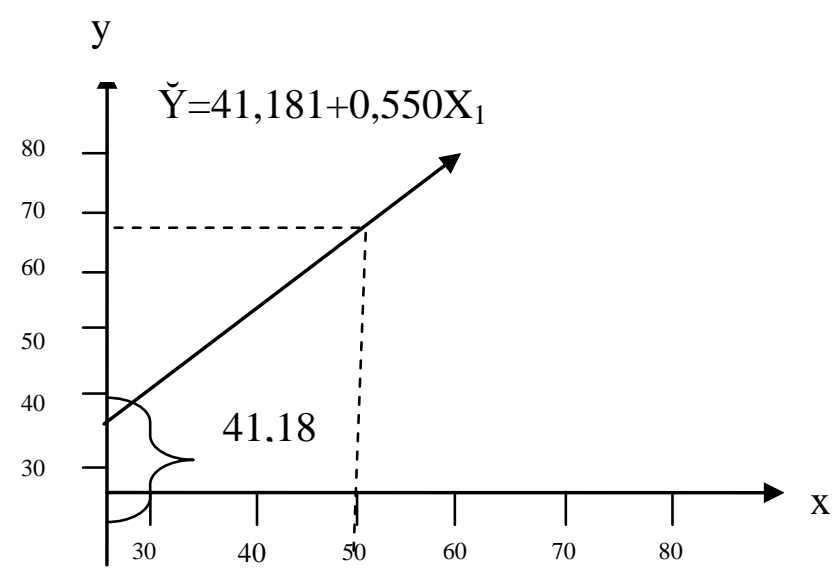

Gambar 01 Garis regresi $\breve{Y}=41,181+0,550 \mathrm{X}_{1}$

Dilanjutkan mencari uji $t$ diperoleh $t_{\text {hitung }}=0,487>t_{\text {tabel }}=0,159$, jadi dapat dikatakan terdapat pengaruh yang signifikan kecerdasan emosional terhadap kompetensi pengetahuan IPS (Y). Mengetahui kontribusi variabel $\left(\mathrm{X}_{1}\right)$ terhadap $(\mathrm{Y})$, nilai koefisien korelasinya di kuadratkan $\left(\mathrm{r}^{2}\right)$. Koefisien determinasi $\left(\mathrm{r}^{2}\right)=\left(0,450^{2}\right)=0,203$ atau $23,8 \%$ ini berarti Sumbangan atau kontribusi kecerdasan emosional terhadap kompetensi pengetahuan IPS adalah 23,8\%.

Analisis uji hipotesishipotesis yang ke dua $\mathrm{H}_{0}$ : tidak terdapat pengaruh kebiasaan belajar terhadap kompetensi pengetahuan IPS siswa kelas V Gugus Mohhamad hatta Kecamatan Denpasar Selatan tahun ajaran 2018/2019. Berdasarkan perhitungan diperoleh data koefisien $a=49,706$ dan $b=0,433$. Jadi model persamaan regresinya adalah $\breve{Y}=49,706+0,433 \mathrm{X}_{2}$ atau kompetensi pengetahuan IPS = 49,706+0,433 kebiasaan belajar.

Hasil persamaan regresi tersebut dapat digambarkan dengan garis regresi yaitu sebagai berikut.

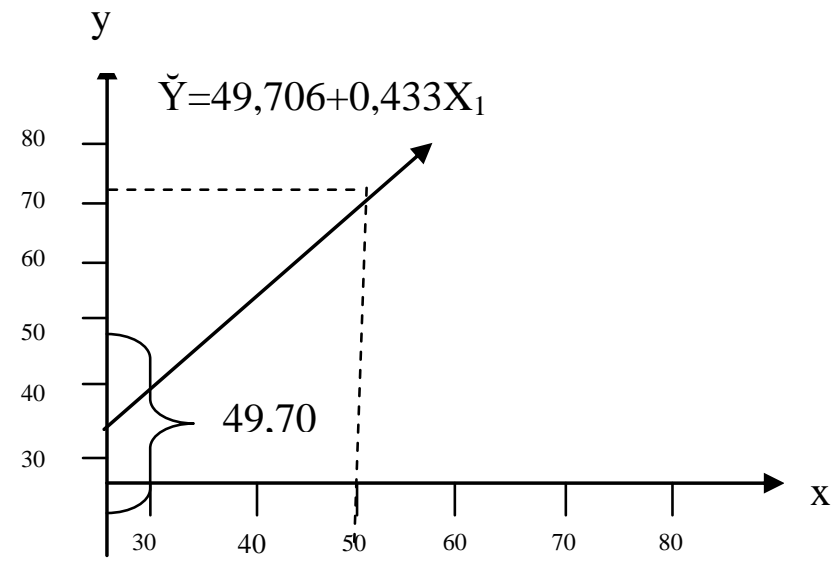

Gambar 02 Garis regresi $\hat{Y}=49,706+0,433 X_{2}$

Selanjutnya nilai $t_{\text {hitung }}$ sebesar 0,397 lebih besar dari $t_{\text {tabel }}$ sebesar 0,159 ini berarti terdapat pengaruh kebiasaan belajar terhadap kompetensi pengetahuan IPS. Untuk mengetahui kontribusi variabel $\left(\mathrm{X}_{2}\right)$ terhadap (Y), nilai koefisien korelasinya di kuadratkan $\left(r^{2}\right)$. Koefisien determinasi $\left(r^{2}\right)=\left(0,397^{2}\right)=0,158$ atau $15,8 \%$ ini berarti Sumbangan atau kontribusi kecerdasan emosional terhadap kompetensi pengetahuan IPS adalah 15,8\%. Sehingga dapat disimpulkan $\mathrm{H}_{0}$ untuk hipotesis I dan II ditolak. 
Analisi uji hipotesis ketiga menggunakan teknik analisis regresi ganda, setelah nilai regresi ganda. Berdasarkan perhitungan diperoleh data koefisien $b_{0}=47,376, b_{1}=0,398, b_{2}=0,137$. Jadi model persamaan regresinya adalah $\hat{y}=37,542+0,452 x_{1}+0,141 x_{2}$ atau kompetensi pengetahuan IPS $=37,542+0,452$ kecerdasan emosional $+0,141$ kebiasaan belajar.

Hasil persamaan regresi tersebut dapat digambarkan dengan garis regresi yaitu sebagai berikut.

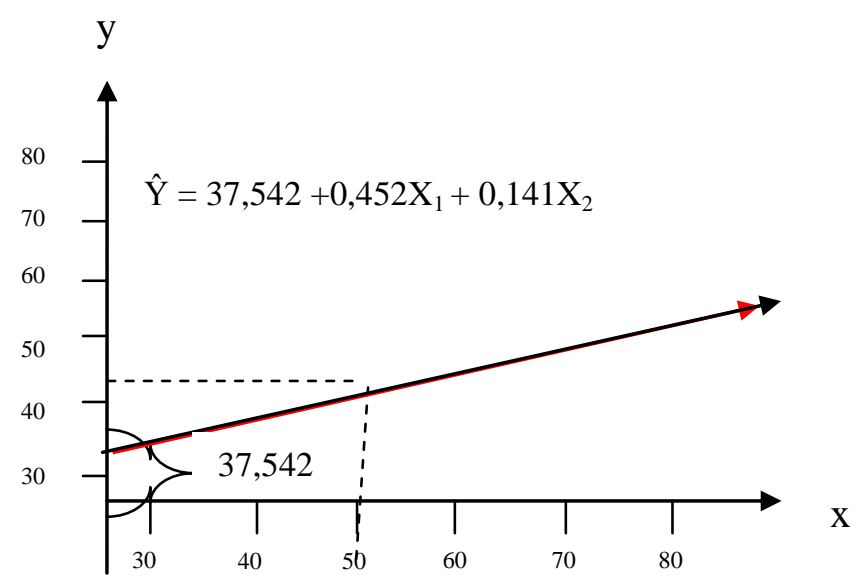

Gambar 03 Garis regresi $\hat{Y}=37,542+0,452 X_{1}+0,141 X_{2}$

Dilanjutkan dengan uji siginfikansi bedasarkan perhitungan uji signifikansi, diperoleh $\mathrm{r}_{\text {hitung }}=$ $0,497>f_{\text {tabel }}=0,159$. Jadi dapat dikatakan terdapat pengaruh yang signifikan kecerdasan emosional( $\left.x 1\right)$ dan kebiasaan belajar (x2) secara simultan terhadap kompetensi pengetahuan ips (y). Berdasarkan hasil dari perhitungan dapat diketahui koefisien determinasi $r^{2}=0,497$ ini artinya bahwa sebesar 24,7\% kompetensi pengetahuan IPS dapat dijelaskan oleh variabel bebas kecerdasan emosional $\left(\mathrm{x}_{1}\right)$ dan kebiasaan belajar ( $\mathrm{x}_{2}$ ). Hasil uji hipotesis I, II, dan III bisa di lihat di tabel 04.

Tabel 03 Rekapitulasi uji hipotesis I,II,III

\begin{tabular}{ccccccccc}
\hline No & $\begin{array}{c}\text { Uji } \\
\text { hipotesis }\end{array}$ & $\begin{array}{c}\text { Taraf } \\
\text { sig. }\end{array}$ & $\begin{array}{c}\mathbf{t} \\
\text { tabel }\end{array}$ & $\begin{array}{c}\mathbf{t} \\
\text { hitung }\end{array}$ & $\begin{array}{c}\mathbf{f} \\
\text { tabel }\end{array}$ & $\begin{array}{c}\mathbf{f} \\
\text { hitung }\end{array}$ & $\mathbf{R}^{\mathbf{2}}$ & keputusan \\
\hline 1 & I & $5 \%$ & 0,159 & 6,181 & 3,91 & 47,408 & $23,8 \%$ & signifikan \\
2 & II & $5 \%$ & 0,159 & 2,135 & 3,91 & 28,516 & $15,8 \%$ & signifikan \\
3 & III & $\% \%$ & 0,159 & 0,497 & 3,06 & 24,441 & $24,7 \%$ & signifikan \\
\hline
\end{tabular}

\section{Simpulan Dan Saran}

Hasil analisis menunjukkan bahwa: 1) kecerdasan emosional memberikan sumbangan efektif atau memiliki koefisien determinasi terhadap kompetensi pengetahuan IPS siswa kelas V SDN Gugus Mohhamad Hatta Kecamatan Denpasar Selatan Sebesar 23,8\% sedangkan sisanya sebesar 76,2\% merupakan pengaruh dari factor lain. Siswa memiliki kecerdasan emosional yang tinggi maka memiliki kompetensi IPS yang baik. Dengan kata lain terdapat pengaruh yang signifikan kecerdasan emosional terhadap kompetensi pengetahuan IPS. 2) kebiasaan belajar memberikan sumbangan efektif atau memiliki koefisien determinasi terhadap kompetensi pengetahuan IPS siswa kelas V SDN Gugus Mohhamad Hatta Kecamatan Denpasar Selatan Sebesar 15,8\% sedangkan sisanya sebesar 84,2\% merupakan pengaruh dari factor lain. Siswa memiliki kebiasaan belajar yang baik maka memiliki kompetensi IPS yang baik. Dengan kata lain terdapat pengaruh yang signifikan kecerdasan emosional terhadap kompetensi pengetahuan IPS. 3) Kecerdasan emosional dan kebiasaan belajar memberikan sumbangan efektif sebesar 24,7\% terhadap kompetensi pengetahuan IPS siswa kelas V SDN Gugus Mohhamad Hatta Kecamatan Denpasar Selatan sedangkan sebesar 75,3 merupakan pengarug dari factor lain, kategori pengaruh yang diperoleh adalah baik antara kecerdasan emosional dan kebiasaan belajar terhadap kompetensi pengetahuan IPS. Semakin tinggi kecerdasan emosional dan kebiasaan belajar maka dapat mempengaruhi kompetensi pengetahuan IPS di sekolah. Dengan kata lain terdapat pengaruh yang 
signifikan secara bersama-sama kecerdasan emosioal dan kebiasaan belajar terhadap kompetensi pengetahuan IPS.

Berdasarkan simpulan di atas dapat di sarankan beberapa hal yaitu: 1) Peserta didik hendaknya meningkatkan kecerdasan emosional dan kebiasaan belajar terhadap dirinya dalam mengikuti proses pembelajaran lainnya. 2) Guru hendaknya mencoba mengembangkan kompetensinya dalam hal mengelola pembelajaran untuk mewujudkan kegiatan pembelajaran yang menyenangkan, efektif, dan mampu meningkatkan hasil belajar siswa. 3) Kepala sekolah hendaknya mengajak guru-guru untuk mengikuti seminar atau pelatihan mengenai upaya meningkatkan hasil belajar siswa dengan menggunakan model pembelajaran yang inovatif. Dan 4) Peneliti lain diharapkan bisa memecahkan dan mencari jalan keluarnya sehingga proses pembelajaran berlangsung secara optimal dan tercapainya tujuan pembelajaran.

\section{Daftar Rujukan}

Agung, Gede. 2016. Statistika Dasar untuk Pendidikan. Yogyakarta: Deepublish.

Aunurrahman. 2014. Belajar dan Pembelajaran. Bandung; Alfabeta.

Dantes, Nyoman. 2012. Metodologi Penelitian Untuk Ilmu-ilmu Sosial dan Humaniora. Singaraja: Universitas Pendidikan Ganesha.

Djaali. 2012. Psikologi Pendidikan. Jakarta : PT Bumi Aksara.

Koyan, I Wayan. 2012. Statistik Pendiikan Teknik Analisis Data Kuantitatif. Singaraja:Universitas Pendidikan Ganesha.

Lasmawan, Wayan. 2016. Pendidikan IPS. Singaraja. Bali:Medikom Indonesia Press.

Setyosari, Punaji. 2015. Metode Penelitian "Pendidikan \& Pengembangan". Jakarta : Prenadamedia Group

Sugiyono. 2017. Metodelogi Penelitian Pendidikan. Bandung: Alfabeta.

Susanto, Ahmad. 2014. Perkembangan Pembelajaran IPS Di Sekolah Dasar. Jakarta: Kencana Prenadamedia Group. 